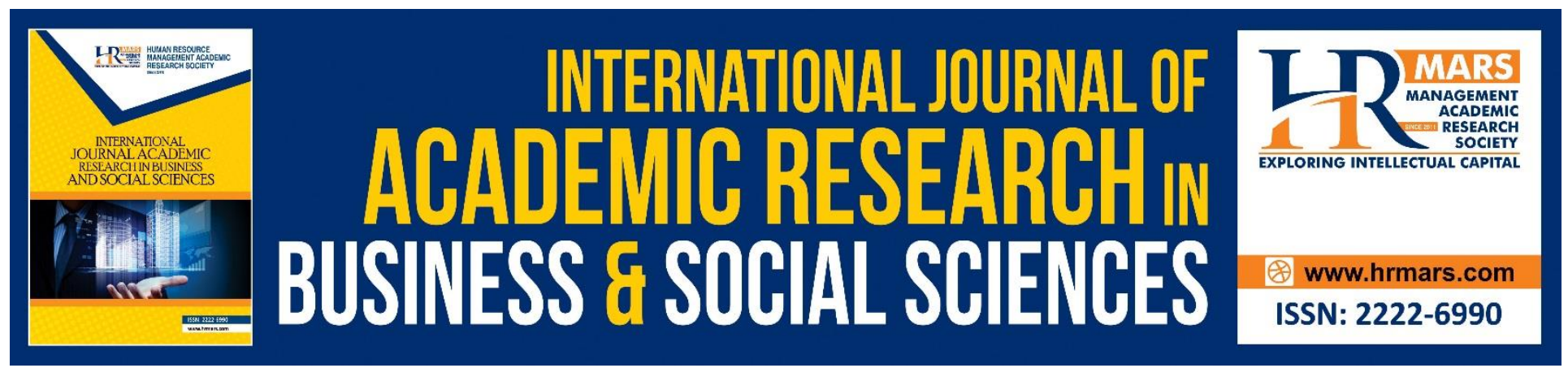

\title{
Corporate Credibility Assessment: The Perception of Chinese Malaysian
}

Irma Yazreen Md Yusoff, Fathan Soetrisno, M. Dyg Affizzah, Hin L. K A.

To Link this Article: http://dx.doi.org/10.6007/IJARBSS/v10-i7/7388 DOI:10.6007/IJARBSS/v10-i7/7388

Received: 16 April 2020, Revised: 20 May 2020, Accepted: 17 June 2020

Published Online: 15 July 2020

In-Text Citation: (Yusoff et al., 2020)

To Cite this Article: Yusoff, I. Y. M., Soetrisno, F., Affizzah, M. D., \& A., H. L. K. (2020). Corporate Credibility Assessment: The Perception of Chinese Malaysian. International Journal of Academic Research in Business and Social Sciences, 10(7), 17-27.

Copyright: (C) 2020 The Author(s)

Published by Human Resource Management Academic Research Society (www.hrmars.com)

This article is published under the Creative Commons Attribution (CC BY 4.0) license. Anyone may reproduce, distribute, translate and create derivative works of this article (for both commercial and non-commercial purposes), subject to full attribution to the original publication and authors. The full terms of this license may be seen at: http://creativecommons.org/licences/by/4.0/legalcode

Vol. 10, No. 7, 2020, Pg. 17 - 27

http://hrmars.com/index.php/pages/detail/IJARBSS

JOURNAL HOMEPAGE

Full Terms \& Conditions of access and use can be found at http://hrmars.com/index.php/pages/detail/publication-ethics 


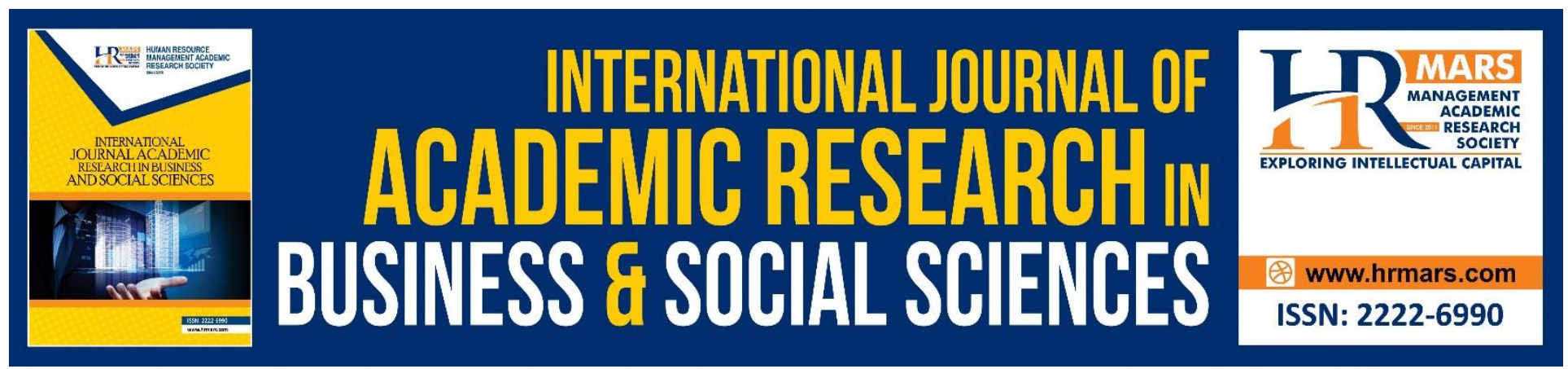

\title{
Corporate Credibility Assessment: The Perception of Chinese Malaysian
}

\author{
Irma Yazreen Md Yusoff, Fathan Soetrisno, M Dyg Affizzah, Hin L. K \\ A. \\ Faculty of Economics and Business, Universiti Malaysia Sarawak, 94300 Kota Samarahan, Sarawak, \\ University College Technology of Sarawak, Universiti Malaysia Sarawak \\ Email: myiyazreen@unimas.my
}

\begin{abstract}
The purpose of this research is to examine the perception of Chinese Malaysian towards corporate credibility. Online questionnaire was created and distributed to collect primary data from the target respondents who are Malaysian with Chinese descendant residing in Penang. 250 online questionnaires were collected and analysed through the use of Statistical Package for Social Sciences (SPSS) for the tabulation of respondents' demographic profile and Structural Equation Modelling Partial Least Square (SEM - PLS) to analyse the relationship between the variables. Based on the hypothesis testing, the results show that customer focus, product quality, expertise and trustworthiness has significant influence on the perception towards organization credibility, while transparency has no significant influence on the perception of Penang Malaysian Chinese towards organization credibility.
\end{abstract}

Keywords: Corporate Credibility, Credibility Index.

\section{Introduction}

Organization credibility is defined by Goldsmith, Lafferty and Newell (2000) as an indicator to measure stakeholders and shareholders believe towards the organization's trustworthiness and expertise. It was also defined as the degree to which the customers or consumers believed that an organization can design and deliver products and services that suits their requirements (Keller, 1998). Hence, organization credibility gives a meaning by how organization package and promotes themselves to the customers in order to build the reputation in their respective sectors.

\section{Measuring Organization Credibility}

There are plenty of previous researches that has developed various kind of measurement scales to measure organization credibility. However, most of the studies faces the same problem: the measurement scales are used without a standardized, trustable and valid member of construct (Newell and Goldsmith, 1997). Researchers used their own respective scales to conduct their own 
INTERNATIONAL JOURNAL OF ACADEMIC RESEARCH IN BUSINESS AND SOCIAL SCIENCES Vol. 10, No. 7, July, 2020, E-ISSN: 2222-6990 @ 2020 HRMARS

studies and thus has absolutely no unity. The only similarity between the scales used is their lack of recognized validity. In order to solve the issue, Newell and Goldsmith (2001) has developed measurement scale to examine organization credibility. The product from the study is called Western Organization Credibility Index. The credibility index is considered as a valid and consistent measurement scale used to measure perception of consumers towards organization credibility.

\section{Malaysian Environment on Organization Credibility}

According to the current population estimates by Department of Statistics Malaysia (2019), Malay Malaysian are made up of 69.3 per cent of the total population, followed by Chinese Malaysian with 22.8 per cent, and Indian Malaysian with 6.9 per cent and another 1 per cent is made up of natives and indigenous ethnics. Malaysia is well known for its multiracial people where each can harmoniously practice their own religion, beliefs, languages, culture and most importantly values. Each race brings their own unique characteristics and values from their upbringing and they are raised very differently compared to those of western societies. Therefore, corporations in Malaysia are very much influenced by the "Eastern ethnic work ethos" that abide by religious beliefs, customs and culture. Due to the cultural differences that exists between Malaysia and the western countries, there is a high possibility that Malaysian perceived organization credibility differently as compared to the western societies. Hence, a thorough study should be conducted in order to examine how Malaysians especially those of Chinese descent perceived organization credibility, and compares their perception with the perception of western standards.

\section{Problem Statement}

The credibility index developed by Goldsmith and Newell (1997) has been a useful tool in helping western organizations to re-examine themselves. However, the index only takes account the western organization without considering that people from different culture may have different opinion and perceptions. As mentioned before, the Asian region is made up of multi-diversified ethnics, which shared different cultures, beliefs, language, values and ethnicity. This factors are crucial as it may be the reason for people from different regions and areas to perceive things differently. Therefore, this study seeks to determine whether Asians perceives organization credibility similarly with the westerns or the other way around due to the differences in continent and context.

\section{Research Objective}

The main objective of this research is to study the factors that influences the perception of Penang Chinese towards organization credibility. The factors being examined are trustworthiness, expertise, product quality, customer focus and transparency.

\section{Literature Review}

\section{Trustworthiness and Expertise}

Windham (2009) carry out a study to determine the impact of organization credibility towards the organizations. Notably, the results from the study shows that men rated the construct regarding trustworthiness higher in the credibility scale constructed. This shows that different gender tends to view organization credibility in different perspectives from each other, which leads to the outcome of the research. Newell and Goldsmith (2001) has conducted a study to develop and standardized scale to measure organization credibility. They start off by reviewing previous studies that are 
conducted with the similar purpose, and found out that past researchers have not come out with a unified, trustable, and valid measure of construct. Trustworthiness and expertise are used as independent variables to measure organization credibility. The study uses five different sets of data to construct a reliable and valid scale to measure perceived organization credibility. The first two sets of data collected are analysed using explanatory analysis and confirmatory analysis, and at the same time measuring the internal consistency of data. The third and fourth sets of data are then used to construct the measure's validity. The last set is then used to compare the measure across different organization.

\section{Other Factors of Credibility}

Goldsmith, Lafferty and Newell (2000) further conducted a study how does source credibility affects consumers' attitude and purchase intentions towards an organization. The dimension used in the study to measure source credibility is trustworthiness, expertise and attractiveness. The results showed that both organization credibility and endorser credibility have huge impacts on affecting consumers' perception. Notably, endorser have a greater influence towards attitude towards-the-ad; while organization credibility has more impact towards attitude-towards-brand and purchasing intention (Lafferty and Goldsmith, 1998). This also shows that organization credibility plays a more crucial role in affecting consumers' perception towards the organization (Goldsmith, Lafferty and Newell, 2000).

Jaso (2011) has conducted a study in order to determine the factors or source credibility and how does source credibility affects persuasive power. The author mentioned that besides trustworthiness, expertise and attractiveness, gender and race always plays an important role in influencing perceived source credibility. The results from the study shows that all dimensions; trustworthiness, expertise, attractiveness, gender and race are all valid factors that affects persuasive power of an organization, which directly means that credibility of the organization is affected by these factors.

McCroskey and Teven (1999) later on did a further study to re-examine the dimension used to construct the measurement scale for perceived credibility, and wishes to improve the validity and the reliability of the previous scale of measurement that is constructed. In this study, the researcher added in a new dimension, goodwill, together with dimension, competence and trustworthiness, to measure perceived source credibility index. From the results, the researchers claimed that goodwill is indeed a valid dimension that can be associated with trustworthiness and competence in the source credibility construct.

\section{Research Methodology}

The target respondent for this study focuses on Malaysians of Chinese descents living Penang. According to Department of Statistics Malaysia (2016), the estimated total population in Penang is approximately 1.72 million and 41.2 per cent of this population were reported to be Chinese descendants by Penang Institute (2015). 250 questionnaires were distributed and collected from the targeted sample.

The data collection instrument is divided into two sections: Section one focuses on demographic information; age, gender, religion, marital status, education level, occupation and monthly income. Descriptive data and single item measure (SIM) with different scale points were used. Whereas Section two includes items related to Respondents' perceptions towards corporate credibility. 
INTERNATIONAL JOURNAL OF ACADEMIC RESEARCH IN BUSINESS AND SOCIAL SCIENCES Vol. 10, No. 7, July, 2020, E-ISSN: 2222-6990 @ 2020 HRMARS

Measures are adapted from Newell and Glodsmith (2001) based on Likert scale ranging from (1) very strongly disagree to (7) very strongly agree.

For the purpose of this study, Frequency Analysis, Descriptive Analysis, Exploratory Factor Analysis (EFA), Pearson Correlation Coefficient and Partial Least Squares Structural Equation Modeling (PLSSEM) is used to analyse the results.

\section{Findings and Discussion}

\section{Respondents Profile}

There are 250 respondents in this study. The respondents are Malaysians of Chinese descents residing in Penang as shown in

Table 1 below.

Table 1: Demographic Profile of Respondents

\begin{tabular}{|c|c|c|c|}
\hline Demographics & & $\begin{array}{c}\text { Frequency } \\
(\mathrm{N}=250)\end{array}$ & Percentage (\%) \\
\hline \multirow{2}{*}{ Gender } & Male & 132 & 52.8 \\
\hline & Female & 118 & 47.2 \\
\hline \multirow{5}{*}{ Age } & 20 and below & 7 & 2.8 \\
\hline & $21-30$ & 230 & 92.0 \\
\hline & $31-40$ & 8 & 3.2 \\
\hline & $41-50$ & 3 & 1.2 \\
\hline & 50 and above & 2 & 0.8 \\
\hline \multirow{4}{*}{ Religion } & Buddhist & 183 & 73.2 \\
\hline & Taoism & 38 & 15.2 \\
\hline & Christian & 24 & 9.6 \\
\hline & None & 5 & 2.0 \\
\hline \multirow{2}{*}{ Marital status } & Single & 234 & 93.6 \\
\hline & Married & 16 & 6.4 \\
\hline \multirow{7}{*}{ Educational level } & $\mathrm{PhD}$ & 4 & 1.6 \\
\hline & Bachelors' Degree & 190 & 76.0 \\
\hline & A - Level & 1 & 0.4 \\
\hline & Diploma & 21 & 8.4 \\
\hline & STPM & 24 & 9.6 \\
\hline & SPM & 9 & 3.6 \\
\hline & UPSR & 1 & 0.4 \\
\hline \multirow{4}{*}{ Occupation } & Student & 208 & 83.2 \\
\hline & Employed & 25 & 10.0 \\
\hline & Self-Employed & 12 & 4.8 \\
\hline & Unemployed & 5 & 2.0 \\
\hline \multirow{3}{*}{ Monthly income } & Above RM3000 & 15 & 6.0 \\
\hline & Below RM1000 & 200 & 80.0 \\
\hline & RM1000 - 2000 & 21 & 8.4 \\
\hline
\end{tabular}


INTERNATIONAL JOURNAL OF ACADEMIC RESEARCH IN BUSINESS AND SOCIAL SCIENCES

RM2001-3000 $14 \quad 5.6$

\section{Assessment of Measurement Model}

\section{Factor Loading}

The value of the factor loading is higher than 0.5 which is considered to be at a significant level (Gaol, Mars and Saragih, 2014). Thus, the loading with a value less than 0.5 should be removed since it is not significant (Memon and Rahman, 2014). All of the elements are examined to indicate whether it is considered significant. The elements that has factor loading value higher than 0.5 is then confirmed.

\section{Convergent Validity}

The convergent could be determined by looking into the factor loading, Composite Reliability (CR) and Average Variance Extraction (AVE). The Composite Reliability (CR) of all measurement elements has a value greater than 0.7 . This shows that all elements are fitted in their respective variables relevantly. Furthermore, this also signifies the internal consistency of each construct. Qi, Shen and Dou (2013) claims that when AVE has a value greater than 0.5, the measurement of the latent variance is considered to be a reliable indicator to determine the convergent validity. In addition, the Average Variance Extraction (AVE) for all elements are greater than 0.5 , which proves that the results generated is reliable and possess valid convergent.

\section{Discriminant Validity}

According to Fornell and Larcker (1981), Discriminant Validity (DV) can be determined through Average Variance Extraction (AVE). The researchers also state that the square root of AVE for each construct is larger than the correlation estimate of the construct. Furthermore, all of the constructs shows a valid DV, as all square root AVE value is greater than the other correlation based on comparison of rows and columns.

\section{Variance Inflation Factor}

To prove that each construct is distinct and are measuring organization credibility, the value of VIF for each factor should not exceed 3.3 (Diamantopoulous and Sigauw, 2006). In addition, the VIF values for each construct is lower than 3.3, which indicates that the construct is measuring organization credibility relevantly. 
INTERNATIONAL JOURNAL OF ACADEMIC RESEARCH IN BUSINESS AND SOCIAL SCIENCES

Vol. 10, No. 7, July, 2020, E-ISSN: 2222-6990 @ 2020 HRMARS

\section{Assessment of Structural Model}

Research Model

Figure 1 shows the research model based on the output produced by using Smart Partial Least Square (PLS).

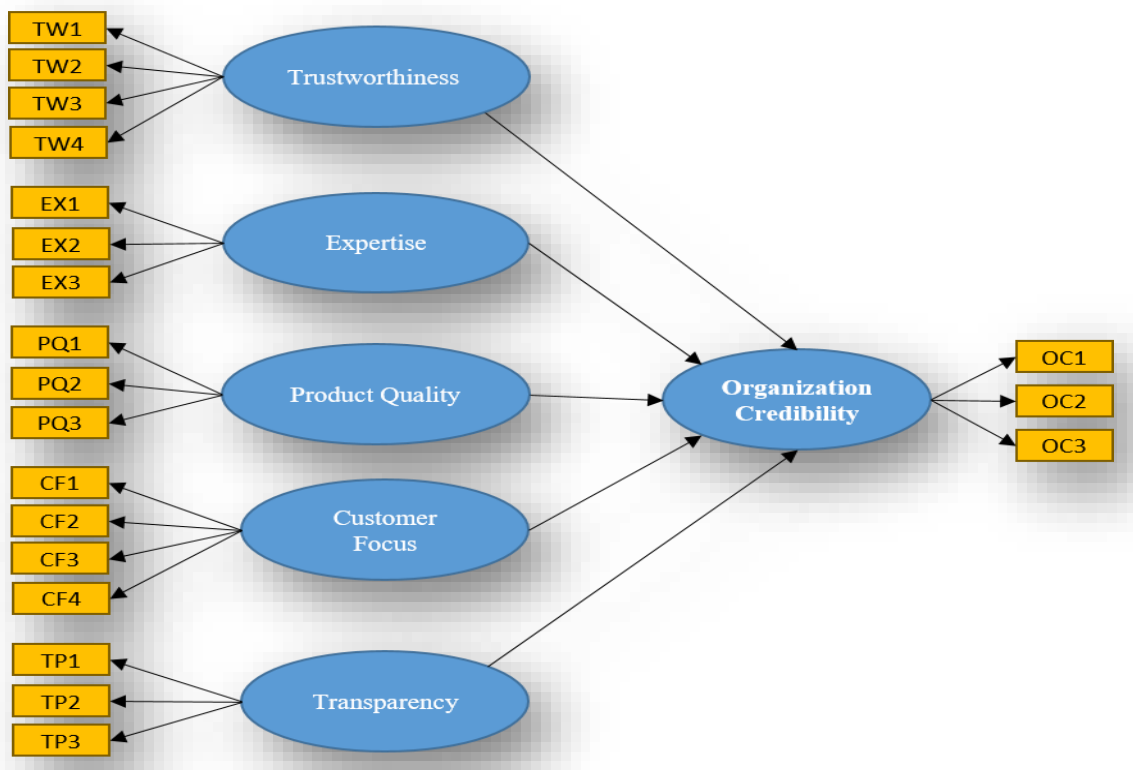

Figure 1: Research Model

\section{Path Co-Efficient Assessment}

From the result as tabulated in

Table 2, it clearly shows that only transparency is not significant (Transparency $\rightarrow$ Organization Credibility, $\beta=-0.003, p>0.05)$. Other factors which includes Customer Focus, Expertise, Product Quality, and Trustworthiness are proven to be significant (Customer Focus $\rightarrow$ Organization Credibility, $\beta=0.282, p>0.05$ ), (Expertise $\rightarrow$ Organization Credibility, $\beta=0.269, p>0.05$ ), (Product Quality $\rightarrow$ Organization Credibility, $\beta=0.207, p>0.05$ ) and (Trustworthiness $\rightarrow$ Organization Credibility, $\beta=0.190, p>0.05)$.

Table 2: Path Co-Efficient Assessment

\begin{tabular}{lcccccc}
\hline & $\begin{array}{c}\text { Direct } \\
\text { Effect }(\boldsymbol{\beta})\end{array}$ & $\begin{array}{c}\text { Sample } \\
\text { Mean }(\mathbf{M})\end{array}$ & $\begin{array}{c}\text { Standard } \\
\text { Error }\end{array}$ & T-statistics & P-value & Significance \\
\hline $\mathrm{CF} \rightarrow$ OC & 0.282 & 0.284 & 0.075 & 3.767 & 0.000 & YES \\
$\mathrm{EX} \rightarrow$ OC & 0.269 & 0.266 & 0.075 & 3.577 & 0.000 & YES \\
$\mathrm{PQ} \rightarrow$ OC & 0.207 & 0.205 & 0.076 & 2.728 & 0.006 & YES \\
$\mathrm{TP} \rightarrow$ OC & -0.003 & 0.011 & 0.081 & 0.042 & 0.967 & NO \\
$\mathrm{TW} \rightarrow$ OC & 0.190 & 0.180 & 0.085 & 2.241 & 9.925 & YES \\
\hline
\end{tabular}

${ }^{*} p<0.01$ (one tail), ${ }^{*} p<0.05$ (two tail)

Note: $C F=$ Customer Focus; $E X=$ Expertise; $P Q=$ Product Quality; $T P=$ Transparency; $T W=$ Trustworthiness; $O C=$ Organization Credibility 
INTERNATIONAL JOURNAL OF ACADEMIC RESEARCH IN BUSINESS AND SOCIAL SCIENCES Vol. 10, No. 7, July, 2020, E-ISSN: 2222-6990 @ 2020 HRMARS

Determination of Co-efficient $\left(R^{2}\right)$, Effect Size $\left(f^{2}\right)$ and Predictive Relevance $\left(Q^{2}\right)$

Table 3 below shows the assessment of Determination of Co-efficient $\left(R^{2}\right)$, Effect Size $\left(f^{2}\right)$ and Predictive Relevance $\left(Q^{2}\right)$ of the independent variables on the dependent variable. The value of $R^{2}$ is 0.650 . This means that the independent variable of this research is capable of explaining 65 percent of the variance in perception towards organization credibility. The Determination of Co-efficient $\left(R^{2}\right)$, ranges from 0 to 1 , and a value greater than 0.5 is considered valid, while the opposite indicates a higher probability error of variance (Santhi et al., 2001). Therefore, the results are proven to be adequate. Besides that, the $Q^{2}$ value is 0.340 for organization credibility, which is greater than 0 . This proves that the independent variables indeed have predictive abilities over organization credibility. Furthermore, the result also shows that all of the independent variables except the transparency construct have a small effect size on organization credibility.

Table 3: Determination of Co-efficient (R2), Effect Size (f2) and Predictive Relevance (Q2)

\begin{tabular}{lcccc}
\hline & $\begin{array}{c}\text { Determination } \\
\text { of Co-efficient } \\
\mathbf{R}^{\mathbf{2}^{*}}\end{array}$ & $\begin{array}{c}\text { Predictive } \\
\text { Relevance } \\
\mathbf{Q}^{\mathbf{2}^{* *}}\end{array}$ & OC & Effect Size*** \\
\hline $\begin{array}{l}\text { Organization Credibility } \\
\text { Customer Focus }\end{array}$ & 0.650 & 0.340 & & \\
Expertise & & & 0.098 & Small \\
Product Quality & & & 0.101 & Small \\
Transparency & & 0.050 & Small \\
Trustworthiness & & 0.000 & None \\
\hline Note: & & 0.038 & Small \\
\hline
\end{tabular}

Note:

${ }^{*} R 2$ interpretation (0.75 - substantial, 0.50 - moderate, 0.25 - weak)

** Q2 interpretation (value larger than 0 indicate that the exogenous construct has predictive relevance of endogenous construct)

*** Interpretation of effect size ( 0.02 to 0.14 - small effect, 0.15 to 0.34 - medium effect, 0.35 and above - large effect)

\section{Discussion}

The study focuses on investigating which factor would affect the perception towards organization credibility. The independent variables consist of customer focus, expertise, product quality, transparency and trustworthiness are examined to determine the relationship with the dependent variable, organization credibility.

\section{Customer Focus and Perception towards Organization Credibility}

The customer focus indeed has a significant influence on Chinese Malaysian perception towards organization credibility. This means that customer-focused organization tends to be perceived as organization with greater credibility compared to others. According to Wang and Lo (2013), customers evaluate and perceive higher credibility towards organization that focuses more on customers and able to identify customers' needs and expectations.

\section{Expertise and Perception towards Organization Credibility}

Expertise is also one of the factor that has the most influence in affecting the perception towards organization, as the results shown, expertise is the factor that has largest effect size among other factors. This is due to the fact that Malaysians believed that expertise could help in improving the 
INTERNATIONAL JOURNAL OF ACADEMIC RESEARCH IN BUSINESS AND SOCIAL SCIENCES

Vol. 10, No. 7, July, 2020, E-ISSN: 2222-6990 @ 2020 HRMARS

company's and product's image with a statistical significance of 9.669 and 5.208 respectively (Rashid, Nallamuthu and Md. Sidin, 2002).

\section{Product Quality and Perception towards Organization Credibility}

Product quality has positive influence on the perception towards organization credibility. The product with great consistency are preferred by the Chinese in Penang. Dardak et al. (2009) also states that consumers tend to perceived organizations which provides clean and healthy products to be more credible compared to other organizations.

\section{Transparency and Perception towards Organization Credibility}

Transparency does not have significant influence on perception towards organization credibility. According to Abdullah Sani and Matsuki (2012), public investors and board are less concerned about the level of transparency of a certain organization regarding concentrated shareholding and public listed family firms.

\section{Trustworthiness and Perception towards Organization Credibility}

Trustworthiness has a significant influence on the perception of Penang Chinese towards organization credibility. As stated by Hovland et al. (1953), trustworthiness is one of the important aspects that should be taken account while measuring credibility.

\section{Conclusion}

Based on the findings of this study, it is evident that, Customer Focus, Expertise, Product Quality, and Trustworthiness have a significant influence towards Chinese Malaysian perceptions on organization credibility. Being Expertise as having the largest effect on their perception, followed by Customer Focus, Product Quality and Trustworthiness respectively. As mentioned earlier, Expertise and Trustworthiness factor were adapted from the Western Organization Credibility Index developed by Newell and Goldsmith (1999) whereas the authors have included other factors such as Customer Focus, Product Quality and Transparency into the research model to fit Malaysian context. However, it is found that Transparency yield no significant effect towards Chinese Malaysian perspective on organization credibility. Hence, it is apparent that the index developed by Newell and Goldsmith is indeed applicable on the context of Penang's Chinese Malaysian, due to the significant influence that it has in affecting their perception towards organization credibility. However, it is recommended for future research to look into developing an index that suits to Malaysian context due to its nature of being diverse in terms of culture, religion and value that provides varied perception and expectation on corporates credibility. From this study, it is also recommended for company to ensure that they position their Expertise strategically to the public while at the same time consistently improve on being trustworthy and provides quality product that meets the need and expectation of the consumers.

\section{Fund}

This study is supported under Fundamental Research Grant Scheme: F01/FRGS/1496/2016Developing and Establishing Malaysian Credibility Index (MOCl), Ministry of Education Malaysia 
INTERNATIONAL JOURNAL OF ACADEMIC RESEARCH IN BUSINESS AND SOCIAL SCIENCES

Vol. 10, No. 7, July, 2020, E-ISSN: 2222-6990 @ 2020 HRMARS

\section{References}

Dardak, R. A., Abidin, A. Z. Z., \& Ali, A. K. (2009). Consumers' perception, consumption and preference on organic product: Malaysian Perspective. Economic and Technology Management Review, 4, 95-107.

Diamantopoulos, A., \& Siguaw, J. A. (2006). Formative versus reflective indicators in organizational measure development: A comparison and empirical illustration. British journal of management, 17(4), 263-282. Retrieved from https://doi.org/10.1111/j.14678551.2006.00500.x

Department of Statistics Malaysia Official Portal. (2016). Retrieved from https://www.dosm.gov.my/v1_/

Department of Statistics Malaysia Official Portal. (2019). Retrieved from https://www.dosm.gov.my/v1/index.php?r=column/pdfPrev\&id=OVByWjg5YkQ3MWFZRTN 5bDJiaEVhZz09

Fornell, C., \& Larcker, D. F. (1981). Evaluating structural equation models with unobservable variables and measurement error. Journal of marketing research, 18(1), 39-50. Retrieved from https://doi.org/10.1177\%2F002224378101800104

Goldsmith, R. E., Lafferty, B. A., \& Newell, S. J. (2000). The impact of corporate credibility and celebrity credibility on consumer reaction to advertisements and brands. Journal of advertising, 29(3), 43-54. Retrieved fromhttps://doi.org/10.1080/00913367.2000.10673616

Goldsmith, R. E., \& Newell, S. J. (1997). Innovativeness and price sensitivity: managerial, theoretical and methodological issues. Journal of Product \& Brand Management. Retrieved from https://doi.org/10.1108/10610429710175682

Gaol, F. L., Mars, W., \& Saragih, H. (Eds.). (2014). Management and technology in knowledge, service, tourism \& hospitality. CRC Press.

Hovland, C. I., Janis, I. L., \& Kelley, H. H. (1953). Communication and persuasion. Retrieved from https://psycnet.apa.org/record/1953-15071-000

Jaso, E. (2011). The Dimensions of Source Credibility and Salesperson Persuasion. Retrieved from https://digitalcommons.calpoly.edu/cgi/viewcontent.cgi?referer=https://scholar.google.m/ \&httpsredir $=1 \&$ article $=1080$ \& context $=$ comssp

Keller, K. L. (1998). Branding perspectives on social marketing. ACR North American Advances. Retrieved from https://www.acrwebsite.org/volumes/7887/volumes/v25/NA-25

Lafferty, B. A., Goldsmith, R. E., \& Newell, S. J. (2002). The dual credibility model: The influence of corporate and endorser credibility on attitudes and purchase intentions. Journal of Marketing Theory and Practice, 10(3), 1-11. Retrieved from https://search.proquest.com/docview/212165370?fromopenview=true\&pqorigsite=gschola $r$

McCroskey, J. C., \& Teven, J. J. (1999). Goodwill: A reexamination of the construct and its measurement. Communications Monographs, 66(1), 90-103. Retrieved from http://www.jamescmccroskey.com/publications/180.pdf

Memon, A. H., \& Rahman, I. A. (2014). SEM-PLS analysis of inhibiting factors of cost performance for large construction projects in Malaysia: perspective of clients and consultants. The Scientific World Journal, 2014. Retrieved from https://doi.org/10.1155/2014/165158 
INTERNATIONAL JOURNAL OF ACADEMIC RESEARCH IN BUSINESS AND SOCIAL SCIENCES Vol. 10, No. 7, July, 2020, E-ISSN: 2222-6990 @ 2020 HRMARS

Newell, S. J., \& Goldsmith, R. E. (2001). The development of a scale to measure perceived corporate credibility. Journal of business research,52(3), 235-247. Retrieved from https://doi.org/10.1016/S0148-2963(99)00104-6

Rashid, M. Z. A., Nallamuthu, J., \& Sidin, S. M. (2002). Perceptions of advertising and celebrity endorsement in Malaysia. Asia Pacific Management Review, 7(4).

Rosner, B., \& Glynn, R. J. (2007). Interval estimation for rank correlation coefficients based on the profit transformation with extension to measurement error correction of correlated ranked data. Statistics in medicine, 26(3), 633-646. Retrieved fromhttps://doi.org/10.1002/sim.2547

Santhi, C., Arnold, J. G., Williams, J. R., Dugas, W. A., Srinivasan, R., \& Hauck, L. M. (2001). Validation of the swat model on a large rwer basin with point and nonpoint sources 1. JAWRA Journal of the American Water Resources Association, 37(5), 1169-1188. Retrieved from https://doi.org/10.1111/j.1752-1688.2001.tb03630.x

Shen, J., \& Dou, R. (2013). The 19th international conference on industrial engineering and engineering management. E. Qi (Ed.). Springer. Retrieved from https://link.springer.com/book/10.1007\%2F978-3-642-38427-1

Wang, L. H., Chiang, I. P., \& Lo, S. H. (2017). Customer engagement behaviour in social media advertising: Antecedents and consequences. Contemporary Management Research, 13(3). Retrieved from https://doi.org/10.7903/cmr.17673

Windham, C. C. (2009). The Impact of Organizational Source Credibility and the Factors that Contribute to Opinion Leaders' Decisions to Diffuse Information (Doctoral dissertation, University of Florida). Retrieved from http://etd.fcla.edu/UF/UFE0024503/windham_c.pdf 